\title{
A fruitful missional exegesis for a missional hermeneutic and missiology
}

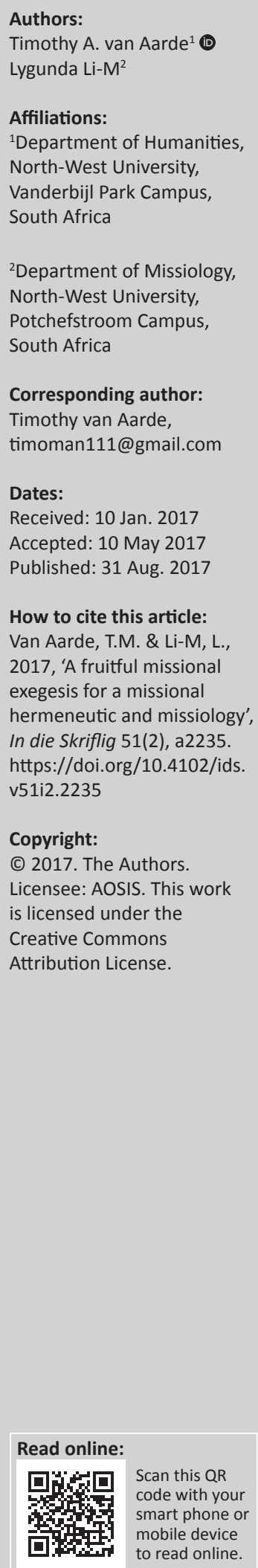

Bosch (1991:497) advocated for a 'third-way' (Bekele 2011:155; Du Plessis 1990:83) in which a deductive and an inductive approach were unified in a creative tension. A fruitful interdependence is achieved by means of the methodological approach of missional exegesis in which text and context are interrelated in a fruitful biblical way reaping the benefits of both the biblical and missional disciplines for a missional hermeneutic. In this approach the formula, $\mathrm{t}($ text $)+\mathrm{c}($ context $)=\mathrm{ms}$ (missional strategy), is suggested by the authors as the starting point for two-directional exegesis from text to context, or context to text, in which neither text nor context is emphasised at the exclusion of expense of the other. It is vital that for a practical interpretation in which the missional context informs the biblical interpretation and vice versa, that a missional hermeneutic and missiology be biblically grounded by the instrument of missional exegesis.

\section{Introduction}

One of the primary questions in the debate between ecumenicals and evangelicals about context in missiology is: Should theology's primary loyalty be to the text or to the context? (cf. Du Plessis 1990:83). ${ }^{1}$ Text and context are interdependent. Rather than advocating for the primacy of text over context, another relation can lead to a fresh and creative understanding, namely a relation which does not use primary and secondary language to categorise the text or context as more important. It is an approach which neither diminishes the text nor the context, nor emphasises the one at the expense of the other. It is impossible to completely separate ourselves from our context, and thus it is not possible to read Scripture in a cultural vacuum. We always read Scripture through our cultural lens, our theological background and personal experience that shape our interpretation. The message of the gospel and the culture are inextricably bound together so that contextualisation is not merely a matter of communication: decoding and encoding as it is in 'the abstraction-adaption model' (Vanhoozer 2006:100). ${ }^{2}$ Context does not merely affect our understanding of Scripture, but our context shapes our understanding of Scripture. It is the lens through which we look at Scripture. The way in which we interpret or read the biblical text is influenced by our context. The view regarding Scripture as primary and context as secondary has led to one-way bridges that are not truly cross-cultural, or cross the cultural barrier. It is the giving of equal priority to the text and the context that builds a two-way bridge which can be crossed from either side. It is, however, when undue priority is given to the text at the neglect of the context that syncretism is the result. The imposition of outside traditions and practices on a group of people that perceive it as a judgement of their culture evokes a response of cultural resistance, a mechanism of preservation and protection. The failure to understand and penetrate the culture of the specific group of people at a deep level with a contextual gospel leaves the worldview of such people unaffected and untransformed. It is this matter, as a cause of syncretism, which has been overlooked. 'Syncretism often results from devoting too much attention to the outer layers of culture and not enough attention to its inner core or worldview' (Hesselgrave 2006:76). Syncretism creeps in when the integral and symbiotic relationship between text and context becomes skewed and either the text or the context is emphasised at the neglect of the other. Evangelicals place the emphasis on the text and tend to err in the direction of overemphasising the text, while Ecumenicals place undue importance on the context at the neglect of the text. ${ }^{3}$ It is the false dichotomy between text and context in missions which in essence is the penultimate cause of syncretism. In addressing this false dichotomy Vanhoozer (2006:105) writes: 'It is not a matter

1.Bosch (1991:22) asserts that for authentic Christian mission in every sociopolitical and historical context it is necessary to "test continually whether its understanding of Christ corresponds with that of the first witnesses'.

2.Stephen Bevans (2002) calls this the translation model.

3.The critical relationship between text and context as a cause of syncretism has been overlooked. It is evident in the one-sided identification of the cause of syncretism as the underemphasis of the text. It is evident in views such as 'syncretism creeps into a church when authenticity to the context becomes the most important priority' (Ott et al. 2010:276). 
of excluding either element .... but rather of doing appropriate justice to both'. It is to the extent that the biblical teaching has been conveyed without being contextualised, a separation of text and context, that Christianity is combined with former animistic religions and has resulted in manifestations of syncretism. In the South African context syncretism is manifested in the form of the sacrifice of goats during the worship service of many AICs.

\section{The problem of a reductionist approach to Scripture}

The root of the problem is a reductionist approach to Scripture. Ott, Strauss and Tennent (2010) posit:

When we speak of contextualizing 'the gospel', we often think of identifying a 'core' or 'kernel' of biblical truth that holds the essence of the gospel, or extracting a transcultural truth from this core, and adapting it into a different context.' (pp. 269-270)

Instead of isolating the key elements of the gospel and seeking to contextualise them it is necessary, as William Dryness (1991:28) suggests, namely to focus more on the comprehensive goal of contextualising Scripture. The contextualising of the Scriptures involves a comprehensive understanding of the life and worldview of the particular group of people to be able to provide a rich and extensive highway between the text and context. 'Christian contextualization that are both authentic and effective are based on careful attention to both the biblical text and the respondent culture' (Hasselgrave \& Rommen 1989:202). The gospel is often reduced to a few isolated proof-texts, which builds a single road instead of a dual motor way between the biblical worldview and the worldview of the particular group of people. Many in the western context focus on the core ideas of the gospel (cf. McGrath 2012:38). It is the process of establishing the cultural scaffolding of sufficiently contextualised Scripture which speaks to the particular context of the group of people that brings about transformation at the level of worldview. One of the problems of contextualisation is that missionaries interpret the culture of another group of people through their own cultural lens and in doing so transmit their own worldview instead of the biblical worldview. Worldview shares a symbiotic relationship culture. Worldview includes ideological factors and value system, cultural elements comprised of the influence of a society's institutions and customs (cf. Heselgrave \& Rommen 1989:55). A second problem is that there is a misconception in missions that there is only one cultural bridge which has to be crossed, while in fact there are multiple cultural bridges influenced by the perception of the world, cognitive processes, linguistic forms, behavioural patterns, social structure, and motivational dimensions. Biblical scholarship takes as primary the worldview and culture of the text and missiology the culture of the specific group of people. These disciplines work from different sides of the bridge: the biblical discipline beginning with the worldview of the text and the interpreter and the discipline of missiology with the specific group of people and the interpretation of the hearers.

\section{The need for a missional exegesis for missiology}

A gap exists between the art of theological or biblical scholarship and the missiological vocation of the community of faith (cf. Bekele 2011:154). It is a gap that was identified by Bosch who sought to establish a relation between what can be termed as 'the homecoming of a wandering theology' (Bekele 2011:154) and the rediscovery of the missional life of the community of faith. The goal of Bosch was to bring scholarship to mission study in order to free it from 'overly specific articulations of mission on the basis of "particularity of preference"' (Bekele 2011:154). Bosch (1986:70) argues persuasively that both disciplines - biblical and missiological are necessary. Bekele (2011) says that:

Biblical scholarship guards against the tendency to read one's own preconceptions into the text without regard for its original meaning, while missiology pushes biblical studies away from a fixation on the ancient context so as to be open to what the Bible means today. (p. 154)

Bosch (1991:497 in Bekele 2011:155; cf. also Du Plessis 1990:83) attempts to steer a path between these two disciplines, a 'third way' which 'intends to take into account both (1) the historical-critical and theological approaches and (2) the whole inspired thrust of the biblical message'. Bekele (2011) correctly identifies the inadequacy of the 'third way' of Bosch and shows that

he weakens one dimension of that very dialectic when he promotes an understanding of the Bible as the authors' interpretation of divine revelation, as opposed to the Bible itself as being a revelatory record (p. 155).

A failed marriage has taken place between biblical scholarship and missiology because the evangelical tradition has adopted a deductive hermeneutical approach and the ecumenical an inductive approach in which the strengths and weaknesses of each have not been recognised. The weakness of the deductive method of the Evangelicals as identified by Bosch, is that the Bible is read in terms of the interpreters own context. ${ }^{4}$ The weakness of the inductive method of the Ecumenicals is that 'context can become more than just a "hermeneutical key"' (Bosch 1980:25). Bosch (1986:70-76) only recognises the weakness and not the strengths of these methods and does not integrate them in his 'third way' (Bosch 1991:497-498). His proposed resolution to the antithesis between the meaning of the biblical text in its own time and what it means now, between a deductive and an inductive hermeneutical framework, is to treat the meaning then and the meaning now as interdependent forces in a creative tension (cf. Bekele 2011:154). This can be compared to a dance, a dance in which the connection between the absolute claims of biblical scholarship and the contemporary praxis of missiology does not truly come to a fruitful interdependence, because it depends upon both partners continuing to dance.

4.Bosch (1980) writes that there is "no such thing as a purely deductive method. Evangelicals are deceiving themselves for ... [one] reads the Bible in terms of [one's] own context (p. 25) 
The approach of Bosch 'raises a question about the reliability of the Scriptures and thereby creates a sense of uncertainty' (Bekele 2011:156) ${ }^{5}$ and his approach 'opens the door to an almost infinite range of subjective interpretations' (Bekele 2011:156). The reason for this is that, although Bosch in Transforming mission (1991) provides excellent missiological analysis of the biblical books he chooses to study, ${ }^{6}$ he does so by means of a missional hermeneutic in which text and context are not interrelated in a fruitful way. The authors of this article advocate for a missional exegesis as a means of an interdependence of the biblical and missiological disciplines and the working mechanism of a missional hermeneutic.

\section{Missional exegesis is more than a biblical theology and exegesis}

Biblical theology and exegesis seek to understand what the historical context is of the text. They also seek to give a present meaning to the content of the message. 'Biblical theology serves as a bridge between exegesis and such contemporary use primarily in that it pulls together the Bible's particular teachings into a coherent whole' (Fanning 2006:285). Missional exegesis strives to understand both what the biblical text meant in the past and what it means today in regard to God's holistic and global mission. The authors propose that missional exegesis extends beyond the findings of theological exegesis and does so by identifying some general principles for mission theory and practice in a particular mission's context and applying them in the exegesis. It is applied to the text by means of a meeting of the perspective of personal missional experience of the biblical author with the context of the interpreter, which authenticates the content of the message and draws the reader into a dialogue with the text, and so endeavours not to err in terms of the text. Missional exegesis endeavours not to err in terms of the context as it is not exegesis for the poor, but draws the poor into dialogue with the text and so it is exegesis by the poor through the identification with the original author by the reader. The poor have a unique vantage point. They are insiders and missional exegesis enlightens the poor as readers to the principles of interpretation and empowers them to interpret the message through the framework of their own socio-political cultural lens. It is more than the application of the content of theological exegesis, but draws the readers to fruitfully engage with the text from their unique contextual vantage point to participate in God's mission, the missio Dei. It necessitates a missional response by the reader, a contextual response in which an identification with the missional spirit of the original author leads to a unique contextual response by the reader. Biblical theology and exegesis does not necessarily lead to a concrete missional response, attitude, behaviour, actions and social renewal.

5.j.G. du Plessis (1990:83) makes the valid point that Bosch cannot sustain his conviction that all subsequent missions should be assessed on the basis of the conviction that all subsequent missions should be assessed on the basis of the diminishing the Scriptures' revelatory essence (cf. Bekele 2011:155).

6.Bosch bases his arguments in Transforming missions on the New Testament and references predominantly only five biblical books.

\section{Missional exegesis is more than a mere exegetical study}

In one of the theological schools in the DR Congo there was a debate whether or not exegetical studies of Genesis 12:1-3 should lead to theological application. While one group promoted a 'pure exegesis' interested in the effort to only understand the original message without any other comment from the exegete, another group suggested that any exegetical study should lead to a theological interpretation and practical application in terms of a missional response. ${ }^{7}$ Indeed, this debate is not new (cf. Kaizer 1981). It is simply the continuity of which occurred in the Western-based theological institutions now being echoed by their African alumni.

Experts of biblical studies have experienced the dualistic tension of doing exegesis without or with application. Although the task of exegesis is to determine the meaning of the passage of Scripture, some exegetes believe that their responsibilities should stop with the past. The implication is that having discovered what the text meant and the missional actions of the author in the past, they are not trying to go any further to what the passage would also mean in terms of a missional response now. The method of biblical interpretation consists of more than an analysis of the context of the text, syntactical, verbal, theological, and homiletical analysis (Fee \& Stuart 2002:5-154; Hayes \& Holladay 2007:34-160). It must include a missional reflection and application. Michael J. Gorman (2009:63-167) suggests the following seven elements of biblical exegesis:

- Survey (first impressions)

- Contextual analysis (historical, socio political, cultural, literary, rhetorical, and canonical contexts)

- Formal analysis (form, structure, and movement of the text)

- Detailed analysis of the text ('careful scrutiny of every word, phrase, allusion, grammar point, and syntactical feature')

- Synthesis: theological interpretation (determining the main point[s] of the text)

- Reflection: theological interpretation (determining the meaning of the text 'for readers other than the original ones')

- Expansion and refinement of the exegesis (using the tools and work of biblical scholars for further clarification)

To these elements still another one may be added:

- Missional reflection and application (using the insights from cultural exegesis to inform the application of the text. An essential question is whether the reading of the text from within a specific culture constitutes part of the meaning of the text.)

For Gorman (2009:63-174) and other aforementioned authors, biblical exegesis is the process of moving from What? to So what?. Following the same step, this article goes beyond the

7.A single school could not be named and singled out, because this is a general debate in almost all theological schools in the Congo. It would also not be good practice to single out a school which would be unethical. 
common understanding of exegesis being the process of seeking to understand what a text means or communicates on its own' (Grenz, Guretzki \& Nordling 1999:49) and from a general response to a specific missional response which is contextual. Otherwise missional exegesis would be an empty intellectual entertainment if it is divorced from missional application.

The abovementioned debate which is essential to the debate of the application of theological exegesis in the context of missiological studies has a more specific orientation. The following questions are important: Are exegetical studies essential to missiology? If so, to what extent should such a statement be true? Is missiological exegesis the same as theological exegesis? If not, what would be the particularity of missiological exegesis? The relevance of this kind of debate will certainly depend on one's missiological presupposition and ministerial context. While in the Central African region such a debate is yet to be initiated, exegetical works undertaken in the context of both missiological and theological studies follow the classical method of biblical exegesis. Most often a distinct difference which would exist between works done in both contexts is not perceptible. This article contends that a missional exegesis which strives to understand both what the biblical text meant in the past and what it means today in regard to God's holistic and global mission, is one of the best ways to secure the nature of the discipline of missiology in the future.

In Interpreting the Bible with the poor, Larry W. Caldwell deals with biblical exegesis under the title, 'Interpreting the Bible with the poor'. He sees the third horizon as that of Ethnohermenuetics (Caldwell 1986:169-193). The author uses the case study of urban poor in the Philippines and focuses his preoccupation on how to help the poor do better Bible interpretation and theology or missiology. Caldwell argues that 'good Bible interpretation is basic to the doing of good theology and missiology' (Caldwell 2013:175). He then proposes that, while promoting the interplay between textual and cultural exegesis, we should put equal emphasis on both instead of on the textual exegesis, which has most often overshadowed the biblical interpretation programs. For him, 'it is in the exegeting of the culture where we increasingly will meet the needs of the church among the poor in the 21st century' (Caldwell 2013:188) and he crosses the presuppositional bridge from one-side, the side of context. Despite its much narrowed missiological concern of 'the needs of the church among the poor', Caldwell's reflection is worth reading because it examines strategies for exegeting both the biblical text and the culture of the audience. Most interestingly, Caldwell's (2013:188-192) section on 'Strategies for exegeting the text' relates to our focus on missional exegesis explained later in this article. However, his 'Strategies for exegeting the culture of people' deals mostly with intercultural communication and doesn't provide strategies to address felt needs at minimal level, midlevel and maximal level.

8.Caldwell questions the supremacy of the historical-critical method and suggests an ethnohermeneutical model that allows for 'culturally appropriate hermeneutical relativism' (cf. Caldwell 2005:169-193).
Caldwell's (2013:188-192) section on 'Strategies for exegeting the text' provides a three-fold range of reading strategies someone would like to use to exegete the biblical text. By 'reading strategies' the author simply refers to 'the tools that readers need [in order] to properly understand the text'. The three reading strategies include the following:

- Minimal reading strategies which require less training. The tools are reading a specific text, reading in the light of the text's immediate context, and reading in the light of the context of the chapter or the book.

- Mid-level reading strategies which require intermediate training. The tools are analysing the literary genre and possible implications, using a concordance for word studies, and using a Bible dictionary or commentary.

- Maximal reading strategy which requires advanced training. The tools are using Hebrew or Greek for word studies, using advanced exegetical commentaries, and reading the text and context in Hebrew or Greek. ${ }^{9}$

A critical question can be asked from Caldwell's (2013:188192) three-fold reading strategies: What reading strategies are appropriate for Bible interpretation done with the poor? Eventually, even Caldwell could not expect only one perfect answer. While he suggests that the maximal reading strategies cannot be used for the poor, he also faces the difficulty of defending his opinion since the concept poor is relative. Furthermore, the fact is that even 'financial and material poverty' does not prevent someone from being intelligent. It is through biblical exegesis that we try to find out how the past message conveyed in the Scripture contributed to God's mission in the past. Missional exegesis has the further step to determine how it contributes to God's mission today, both locally and globally. It is through missional exegesis that 'we bridge the gap between "mission then" and "mission now" (Bekele 2011:153). It is through crossing the contextual bridge that biblical exegesis becomes missional exegesis. It is not simply a theological exegesis which focuses on what God is or does in general in and for the world, but what God does in a specific cultural and missions context. Missional exegesis tries to demonstrate what God is and does to the world through his people (e.g. the church) in a specific context. A clear difference then exists between theological exegesis (God's mission in general) and missional exegesis (God's mission of holistically and globally saving humankind through the church in a particular cultural or missions location).

\section{Missiological exegesis and cultural and historical interpretation}

The authors, thus, propose that missional exegesis is ultimately textual and contextual, that is, it arises from a specific cultural context and it addresses that cultural context through the application of Scripture to a specific cultural or missions context. The central task of theological exegesis is to interpret the Bible in new cultural contexts by relating the

9.Long time Professor of Missions and Hermeneutics, Larry W. Caldwell, is currently visiting Professor of Intercultural Studies at Sioux Falls Seminary, USA, and director of Training and Strategy for Converge Worldwide. 
past historical context of the Bible to a specific cultural context in which the interpreter and audience belongs to the same cultural context. Missional exegesis recognises that there are other bridges which must be crossed. It is not exegesis which is done from above and from outside of the cultural context, but from below and from within a specific cultural context, often by an outsider. Missional exegesis is not only limited to the mission field, but applicable in multicultural contexts. Theological exegesis moves in a certain direction, from text to context, whereas missiological exegesis can move in two directions, from text to the context, or from the context to the text, which is necessary in a multicultural context. This kind of exegesis is a more vital and practical interpretation of Scripture in which understanding is a matter of being intimately emerged in a cultural context. Vanhoozer (2006) declares:

Interpreters are never disembodied minds but embodied persons, persons who are male or female, persons who inhabit a particular place in space and time and so are susceptible to historical and cultural conditioning. (p. 94)

In missional exegesis, cultural presuppositions are recognised together with presuppositions from the interpreters own theological background.

\section{The distinction between Gadamer's understanding of context and context in missional exegesis}

Missional exegesis has to be distinguished from the approach of Hans-George Gadamer (2002) who believes that the scientific method which uses exegetical tools and techniques detaches and distances the reader from the matter of the text. Hermeneutics for Gadamer (2002:180) is a matter of an ongoing conversation with a continuously changing text, ${ }^{10}$ 'to interpret is to enter into dialogue with the text' (Vanhoozer 2005:18), whereas for the authors missional exegesis is an ongoing dialogue between the dynamic truth of the text and the context. ${ }^{11}$ Understanding the text for Gadamer (2002:378) is a matter of the 'fusion of horizons', that of the text and the horizon of the present context of the interpreter. This means that the interpretation of the text is determined by an experience of the text (cf. Gadamer 2002:xxviii). ${ }^{12}$ The approach of Gadamer is not truly a crossing over of the hermeneutic bridge, but a conversation with the text in terms of an experience with the text (cf. Vanhoozer 2005:19). It is an informing of the experience of the present reader emerged in the experience of the culture and worldview of the text devoid of method. His hermeneutic does not follow 'rules of interpretation', but 'reading from one's lived experience' (cf. Vanhoozer 2006:95). It is about the relation of the 'world of the reader' (one's political, cultural, social context) with the

10.In Gadamer's (2002:383) words: 'it is generally more correct to say we fell into a conversation'.

11.The approach of Gadamer focuses on the experience of the text, but as 'one critic has pointed out: "We can have an experience of the disclosure which leads us not to truth but to untruth"' (Vanhoozer 2005:18).

12.Gadamer shifted the emphasis away from the intention of the author and agency to location (cf. Vanhoozer 2005:19-20). 'world of the text' (cf. McDonald 1990; Míguez 2000 in Vanhoozer 2006:94) without the application of a method of interpretation. This implies it is based on a pre-understanding (a preliminary idea of what the text is about) without ensuring that such a reading is correct and biblical through an exegetical study of the text. The textual meaning becomes relative at the point of engagement if it only is cultural and historical without being informed by biblical exegesis. In the view of the authors one's political, cultural, social, and theological context, holistic context, is to engage with Scripture. It is the engagement of the holistic context with text in a missions or missional context which, for the authors, validates the necessity of missional exegesis.

Missional exegesis gives primacy to both the text and the context. Exegesis is done of the text and the culture. It involves biblical and cultural exegesis, an exegesis of the culture, history, motivations, and worldview of a particular cultural group of people. Wright (2006) says:

What persons of one culture bring from that culture to their reading of a text may illuminate dimensions or implications of the text itself that persons of another culture may have not seen so clearly. (p. 39)

The distinction between a missional reading and missional exegesis is that a missional reading uses local and culturally defined categories, often non-western categories, whereas missional exegesis uses both western and non-western categories.

\section{Missional exegesis as an ingredient of a missional hermeneutic}

The missional hermeneutic of C.J.H Wright is much more than a missional reading of the text. A missional hermeneutic is far more than 'aggregating all the possible ways of reading texts, from all the multicolored church and mission contexts around the globe' (Wright 2006:40). Wright grounds a missional hermeneutic in the grand narrative of God, which is the basis for a theology of mission (and practice), in the mission of God (cf. Wright 2006:45). He approaches the Bible from the perspective of a grand narrative and reads the whole as part of the unfolding grand narrative of God and grounds it in biblical theology. This approach eclipses the human story, the story of mankind often at odds with God's purposes and focuses on unfolding of the grand narrative. A missional hermeneutic of coping in youth ministry practice has been suggested by Victor Counted (2016:85-102). The Bible is more than a unified and single story, it is multiple stories weaved together into the single purpose of God, the one divine purpose in Christ, one consistent revelation of God, one world, and one way of salvation. The approach of Hunsberger (2011), is that he argues that the story of God's mission to the world ought to be the lens through which the believer should read the Bible, has been suggested to be a framework for a fruitful hermeneutic for understanding our nature as humans (Hunsberger in Counted 2016:90). In this approach, the Bible is read in terms of the metanarrative of the missional intention 
of God. However, this does not truly engage with the biblical text in terms of exegesis and a bridge toward assessing the wider missionary significance of the passage for the church today. Counted (2016:91) drawing on Hunsberger (2011), proposes a 'missional hermeneutic of coping', suggesting that such a hermeneutic 'takes God's people back to the task for failing to live in God's character, as the people of God'. His 'missional hermeneutic of coping' is grounded in the metanarrative of the sinful nature of human kind, the fall, and addresses the youth identity crises from a biblical theological perspective. However, he does so without exegetical support and so his hermeneutic provides no concrete resolution. The problem of the identity crises of the youth is well conceptualised, the engagement with the biblical metanarrative an application of Wright's missional hermeneutic, but the absence of a missional exegesis results in the engagement of the issue with the biblical text being non-specific and general and 'the prophetic-missional voice of the youth in crises' (Counted 2016:96) no more than a 'prophetic-pathos' (Mills 2007:110-136 in Counted 2016:96) than an engagement of a specific context with the text. A missional hermeneutic requires a missional exegesis, because the stories of the people and those of a particular culture intersect and the purposes of God are not always so clear and self-evident. It requires a commitment to the content and claim of the gospel itself, which must provide the hermeneutical framework or matrix for assessing all claimed readings of the text (cf. Wright 2006:41). It is through a missional exegesis that 'a hermeneutic of coherence' (Brownson in Wright 2006:41) is established. The question, however, prevails: What is missional exegesis?

\section{The meaning of missional exegesis}

The approach of Wright (2006:40) is to advocate for a 'plurality of interpretation', but not 'pluralism as a hermeneutical ideology'. He advocates for the grammaticohistorical method which in his view can provide such a 'plurality of interpretation', but he does not provide any suggestions and guidelines for its application in a missional context. The contextual leg of missional exegesis requires that the interpreter recognises his own cultural presuppositions. Bosch (1980) commented to his students:

Every one reads the Bible from a particular vantage-point which colours our interpretation. Factors include: (a) our church tradition; (b) our culture; (c) our personal experiences and the way we experience religions; and (d) our social position, such as whether we belong to the privileged or under privileged sector of society. (p. 24)

The distinction between theological and missional exegesis is that theological exegesis recognises only the metaphysical and systemic theological presuppositions which determine the meaning of the text, whereas the latter recognises the cultural presuppositions which effect interpretation. Fanning (2006) is of the meaning:

To understand biblical theology clearly is to understand how it interacts with related disciplines, especially exegesis on the one hand and systematic theology, ethics, preaching, and wider application to Christian living on the other. (p. 281)

The focus of biblical theology is the meaning of the text in synthesis with the theological ideas of the larger book (cf. Fanning 2006:281), but it does not address contextual issues from the discipline of missiology. Missional exegesis is a form of exegesis in which the missional aspects of both the original text and the context of the interpreter and readers are taken into consideration. It serves as a bridge between exegesis and mission theology. 'Exegesis by itself is prone to focus on the individual pieces of text' (Fanning 2006:285). Missions provide the framework within which exegesis is synthesised, and so the two are interdependent. Missional exegesis also roots mission in exegesis and biblical theology. The meaning and role of context in missional exegesis is that there are two contexts that need to be considered, the missional context of the text itself, and the communication context of the message. Context is far more complex in missional exegesis than the fusing of the contextual world of the text and the context of the readers. It recognises the textual context, cultural textual context, cultural context of the interpreter and the cultural context of the specific group of people. Missional exegesis is concerned with the meaning of the text in a specific context, a meaning which is not relativised according to the context of the readers. It is rather a meaning in which the worldview of the original author and his cultural context engages the cultural context and worldview of a specific people through a third culture and worldview, namely the culture worldview of the interpreter. Bosch is persuasive in arguing that 'good exegesis is produced where the exegete's own horizon has been opened in the way the biblical author's horizon was opened' (Bekele 20011:155). The view of Bosch of what constitutes good exegesis can be specifically applied to missional exegesis and what constitutes good missional exegesis. Various aspects of a text will stand out in different cultures, but the text only has one single meaning which is the same in every cultural context. The missional implications drawn from the interpretation, however, will be different in various contexts. It is the reason why 'Bosch points out that there will always be different understanding of missions, since diverse interpretative frameworks emanate from differing contexts' (Bekele 20011:154). It leads to the next question: How does missional exegesis function?

\section{Towards a two-way missional exegesis}

The ongoing discussion about the future of the discipline of missiology should take into account both peripheral and cardinal questions. Unfortunately, the tendency today is to ignore the latter for the sake of human freedom and choices. While peripheral questions give privilege to the issues of migration, social and economic development, mission strategies, et cetera, cardinal questions address core issues which put the essence of missio Dei at stake. Such questions include what missiologists think about the Bible, the person 
and the ministry of Christ, the person and the work of the Holy Spirit, sin and salvation, the church and its role, gospel and its raison d'être (reason for being), et cetera. These are actually old issues, but persistently recurrent today though with some nuances. Therefore, the discussion on the future of missiology should frame new questions. We need to address old issues through new questions due to the ever changing context of the missio Dei.

For this reason, missiological exegesis in the context of missiological studies should not be a mere academic study to prove or disapprove the authenticity or the veracity of a biblical passage. Instead, the exegetical work in this perspective should be undertaken as a research to solve a missiological problem. In other words, a missional exegesis should lead to an applied missiological reflection, undertaken as an answer to an applied researchable question, namely 'What must we understand before we know what to do?' (Turadian 2007:9). He distinguishes the applied question from the conceptual question ('What should we think?') and the practical question ('What should we do?'). In our context of francophone Central Africa where mission studies need to be developed, promoted and contextualised, a missiological reflection should be a problem-based study which addresses applied questions. Missiological reflection should clearly identify a current issue in order to search the appropriate answer in the light of God's Word. It might also start with God's Word in its normative role of guiding human paths and actions, in order to provide a clear godly direction to human struggles. The authors conceptualise a two-way approach to missional exegesis:

- From God's Word (Text) to human context (Context)

- From human context (Context) to God's Word (Text).

This two-fold exegetical movement seems similar to Caldwell's (2013:169-193) 'two step approach' discussed earlier, however, it actually differs in both scope and method. While Caldwell insists on the fact that his 'cultural exegesis' should be more stressed than his 'textual exegesis', we don't treat biblical exegesis and contextual exegesis in terms of priority. Also, while Caldwell's (2013:169-193) 'cultural exegesis' is framed as an intercultural communication tool, our 'contextual exegesis' goes beyond communication; rather it is concerned about the felt needs of the people, God's mission field. In contextual exegesis the interpreter will strive to discover answers to questions of inquiry (what, who, when, why, how). Finally, while Caldwell's two step approach deals with the categories of training the poor to understand God's word, our two-way approach is conceived to help any person to interpret the Bible missionally. The following questions are important: How does a given portion of the Scripture reveal one or another aspect of missio Dei? How can the revealed aspect be applied in the current context of humankind, church, and society? As far as missiological studies are concerned, these questions will set the path for a sound biblical exegesis and contextual or cultural exegesis, which make it uniquely a missional exegesis. Caldwell's reading strategies for biblical exegesis can be used as tools for our textual exegesis, but the steps for this textual exegesis will conform to classical steps of biblical criticism (textual, historical, grammatical, literary, form, tradition, redaction, structuralist and canonical) where applicable (Fee \& Stuart 2002:5-154; Hayes \& Holladay 2007:34-166).

Missional exegesis should lead to an applied missiological reflection, which is actually the fruit or the result of biblical exegesis. Missional exegesis can begin with the context or the text, but it can only be fruitful if it is a reflection on a specific missions or missional context through the lens of Scripture. In this perspective, the missiological reflection becomes the application drawn after an interpretative process punctuated by a sound missional exegesis (textual and contextual or contextual and textual). For this reason the authors propose that missiological reflection as part of missional exegesis is not simply theological, anthropological, sociological, humanitarian, historical, political or economical reflections. Rather it is a reflection which has God's holistic and global mission as object while using research methods borrowed from the abovelisted fields of study.

\section{Missiological reflection: From God's Word to human context}

One of the essential questions of missions is: How do we begin to build our biblical foundation of mission? Do we start from the Bible itself and adapt it to our situation, or do we work in the other direction? (Bekele 2011:153). Buckle (in Bekele 2011:153) writes: 'there is no universal answer'.

Missional exegesis is the understanding of the text in a missions or missional context in which the missional implications of the text are worked out. It also involves the identification of the missional intention of the author of a passage or letter. The exegete will face three challenges when identifying the missional intention of a passage or letter. The first challenge has to do with his or her presupposition about the Scripture. Is the Bible inspired revelation from God, exempt from errors and having authority in all matters of human life? The second challenge will relate to the exegete's understanding of the actual meaning of the content. Does the exegete approach the Scripture in a literal way or in a metaphorical way? The third challenge deals with the exegete's opinion whether the Bible is about who God is and what He does in general for humankind, or about who God is and what he does for the holistic salvation of humankind through his people (church). The question is how the passage under study demonstrates God's mission. The letter to the Ephesians can serve as an example of missiological exegesis from the perspective of the intent and purpose of the letter. In the missional exegesis of Ephesians from this perspective various steps have been identified. The first step has been identified by van Aarde, the second by van Aarde and Lygunda Li-M and a third step by Lygunda Li-M, namely:

1. The identification of the original purpose of intention

2. The relation between the text and missional context

3. Missiological reflections and implications 


\section{The identification of the original purpose of intention of the text as missional}

Individual passages can be identified as being missional, but there are also examples of letters in the New Testament that are written specifically with a missional purpose or intention. In recognising that the purpose of the letter to the Ephesians is missional it is important to realise that the purpose of the author is far more than the authors own attribution of why he wrote, or the identification of a particular problem(s) raised because it has been inspired by the Holy Spirit. The purpose of a letter has to do with the function it has in the corpus of the New Testament and so it is necessary to ask: What is its missional function in the New Testament? The author of a New Testament letter may have had several reasons for having written the letter. 'However, normally in writing a letter, there is a primary reason or purpose though there may also be subsidiary purposes included' (Hoehner 2002:98). The purpose of the letter is that which unites all elements of the letter in the most cohesive manner. Central to missions and a missional interpretation is an exposition of the purpose of God: 'there seems to be widespread agreement that "mission", biblically understood, is first and foremost about the nature, character and purposes of God' (Barram 2007:43). O'Brien (1999:111115 ; 2004:206-219) focuses almost exclusively on the verb

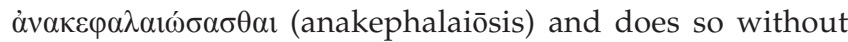
discussing it in relation to the term oikovouía (oikonomia) as a key concept in the letter. O'Brien (2004:213) determines the meaning of the verb $\alpha v \alpha \kappa \varepsilon \varphi \alpha \lambda \alpha \imath \omega ́ \sigma \alpha \sigma \theta \alpha \imath$ (anakephalaiōsis) first within the immediate context before turning to the rest of Ephesians. He, however, overlooks that the verb used in Ephesians 1:9-10 is linked to the concept of oikovouía (oikonomia) and that it is specifically oikovouía (oikonomia) that is developed in the rest of the letter (Eph 3:2 \& 9) (Van Aarde 2016:3). The meaning of oikovoría (oikonomia) in Ephesians 1:10 is 'the plan of God' and this is developed throughout the letter, rather than the idea of unity, the climax of which is the 'summing up of all things'.Van Aarde (2016:3) poses:

The exaltation of Christ is to be understood as the final step, the climactic point, in the summing up of all things in the grand plan of God. Unity stands in a relation to oikovoría (oikonomia) and the plan of God (Eph 1:10; 3:2 \& 9). The unity is secondary; it is the result of the plan of God which is primary in Ephesians. (cf. Van Aarde 2016:1-10)

The reason for this is that in his approach O'Brien (1999:113) has isolated the verb $\alpha v \alpha \kappa \varepsilon \varphi \alpha \lambda \alpha \iota \omega \sigma \alpha \sigma \theta \alpha$ (anakephalaiōsis) from the rest of the phrase. It is only if the verb and noun are taken together that the focal point of the letter is realised, reunification of all of creation expressed as cosmic re-unification in Ephesians 1:22-23 and part of the plan of God, oikovopía (oikonomia), which Christ is executing. The concept of оíкороцí (oikonomia) has been suggested by Van Aarde (2016:1-10) to be the equivalent term for missions in Ephesians. The letter to the Ephesians sets out Christ's cosmic role and the role of the church in the unification of all things. It is this, the execution of the plan of God, which is the focal point of the letter and is missional.

\section{The relation between the text and context}

The second step in missional exegesis is to identify the relation between the Text - Context. The exegete needs to establish the biblical and theological foundation of the subject under consideration. This involves exploring the human struggles, using journalistic questions (what, who, when, how, why) and anthropological methods which include emic (inside perception) and etic (outside perception). The exegete will need to stay focused on the identified problem without too much generalisation. Effort should be made to strictly relate the current context to the text. The exegete is then exposed to the temptation of subjectivity or proof-texting. One of the challenges if we are to develop a biblical theology of mission that serves the church is the challenge how to give local expression to the understanding of text while giving equal attention to the local and global context. Vanhoozer (2006:99) makes a distinction between a good and bad global: 'The bad global is the power of the culture "one" (homogenization); the good global is the awareness of the cultural "many".'

\section{Missiological reflections and implications}

The final step in missional exegesis is to identify the missiological implications for God's mission today. The equation becomes clear: Text + Context $=$ Mission Strategy $(\mathrm{t}+\mathrm{c}=\mathrm{ms}$ ) (Figure 1). In this regard, the 'Mission Strategy' includes both theory and practice of mission. The exegete will strive to draw understandable theories about God's mission today before moving to the proposition of doing God's mission today. The purpose of missional exegesis is to clearly set mission strategies for our time. These strategies need to be biblical and contextual and express the missiological implications. Missional exegesis without missiological implications is a mere academic exercise which does not address the felt needs of the people in a concrete way. In the working out of local missiological implications it is essential to consider also the global implications for the local context. "The "glocal" is the point of intersection between the global and the local, "glocalization" describes the way in which people in a certain locale respond to globalization' (Vanhoozer 2006:99). Clark (2003:113) in Vanhoozer (2006:100-101) continues by saying: 'Going glocal involves more, however, than putting "the thought forms of a contemporary missionary-sending culture in the linguistic dress of a receptor-culture"' ${ }^{\prime \prime}$. The missiological implications ask the questions: What does it mean in the particular place, for the particular group of people, at this particular time?

\section{Missiological reflection: From human context to God's Word}

The alternative point of beginning of missional exegesis is to start with the understanding of the current context.

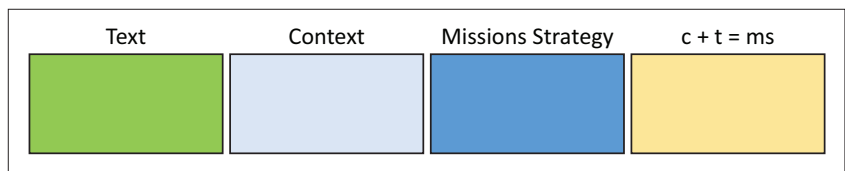

FIGURE 1: The diagram illustrates the process 'From Text to Context'. 
The exegete will face three challenges in beginning with the context. The first challenge has to do with the exegete's understanding of the human-being in regard to the Scripture. Is the human-being God-made or human-modelled reality? The second challenge relates to the understanding of the culture of the people. Does the culture need change or not? The third challenge will be the complexity of social, economic and political realities which deeply affect the people under consideration. To what extent do those realities relate to God's mission?

This approach can be expressed as the direction of Context Text (Figure 2). The exegete needs to establish the current context of the subject under study, using journalistic questions (what, who, when, how, why) and anthropological methods which include emic (inside perception) and etic (outside perception). The next step will be the exploration of the Scripture. The exegete will need to learn from the Word of God without presumption or external influence. Effort should be made to stick to the original context and meaning of the passage under study. The exegete is then exposed to the same temptation of subjectivity as in the first approach.

The final step in this second approach is to discern the missiological implications for God's mission today. The equation becomes clear: Context + Text $=$ Mission Strategy $(\mathrm{c}+\mathrm{t}=\mathrm{ms})$.

\begin{tabular}{|c|c|}
\hline From Text to Context & From Context to Text \\
\hline $\begin{array}{l}\text { The choice of the biblical text } \\
\text { The text can be given to the exegete } \\
\text { or chosen by the exegete. }\end{array}$ & $\begin{array}{l}\text { The choice of the current issues or } \\
\text { trends as they are also felt in the } \\
\text { exegete's context. The subject can be } \\
\text { given to the exegete or chosen by the } \\
\text { exegete. }\end{array}$ \\
\hline $\begin{array}{l}\text { The exegesis of the text using classical } \\
\text { methods of biblical criticism (Gorman; } \\
\text { Hayes \& Holladay) and available } \\
\text { reading strategies (Caldwell). }\end{array}$ & $\begin{array}{l}\text { The exegesis of the context using } \\
\text { journalistic questions (what, who, } \\
\text { when, how, why) and anthropological } \\
\text { methods of emic and etic journalistic } \\
\text { questions }\end{array}$ \\
\hline $\begin{array}{l}\text { Selected subject from the current } \\
\text { context. The choice of the contextual } \\
\text { subject should relate to the biblical } \\
\text { development in stage } 2 \text {. }\end{array}$ & $\begin{array}{l}\text { Select text from the Scripture. The } \\
\text { choice of the biblical text should take } \\
\text { into account current issue or turned } \\
\text { under study, developed in stage } 2 \text {. }\end{array}$ \\
\hline $\begin{array}{l}\text { The exegesis of the context using } \\
\text { journalistic questions (what, who, } \\
\text { when, how, why) and anthropological } \\
\text { methods of emic and etic for each } \\
\text { journalistic question. }\end{array}$ & $\begin{array}{l}\text { The exegesis of the text using } \\
\text { classical methods of biblical criticism } \\
\text { (Gorman; Hayes \& Holladay) and } \\
\text { available reading strategies (Caldwell). }\end{array}$ \\
\hline $\begin{array}{l}\text { Missiological application and } \\
\text { implications should include: }\end{array}$ & $\begin{array}{l}\text { Missiological application and } \\
\text { implications should include: }\end{array}$ \\
\hline $\begin{array}{l}\text { 1) How human felt needs and } \\
\text { God's mission are described } \\
\text { in this study from both the } \\
\text { text and the context? }\end{array}$ & $\begin{array}{l}\text { 1) How human felt needs and } \\
\text { God's mission are described in } \\
\text { this study from both the text } \\
\text { and the context? }\end{array}$ \\
\hline $\begin{array}{l}\text { How the mission of God's } \\
\text { people and human felt needs } \\
\text { are described in this study } \\
\text { from both the text and } \\
\text { context? }\end{array}$ & $\begin{array}{l}\text { How the mission of God's } \\
\text { people and human felt needs } \\
\text { are described in this study from } \\
\text { both the text and context? }\end{array}$ \\
\hline $\begin{array}{l}\text { 3) Which mission strategies } \\
\text { should be framed? }\end{array}$ & $\begin{array}{l}\text { 3) Which mission strategies } \\
\text { should be framed? }\end{array}$ \\
\hline
\end{tabular}

FIGURE 2: The table demonstrates the relationship between text and context.

\section{Missiological application and implications \\ Missiological reflections and implications}

This is a crucial point and there are crucial question which will aid the exegete to ask the so what question: How does this study demonstrate God's mission [through God's people] today? Unless the exegete reaches that point, his or her effort would remain an unfruitful academic speculation.

Essential missiological questions for application are the following:

- How are the mission of God's people and human felt needs described in this study from both the text and the context?

- How are human felt needs and God's mission described in this study from both the text and the context?

- Which mission strategies should be framed?

The exegete must be aware of some challenges discussed for each approach, balancing the strengths and weaknesses of the contextualisation process (Bosch 1991:420-432). According to Goheen (2014) contextualisation is an ongoing process and

the daily task of finding ways to faithfully live out the gospel across the whole spectrum of human life in the midst of a culture shaped by a different set of religious beliefs (p. 288).

C.J.H. Wright (2006) correctly begins with the grand narrative, the divine story which carries divine authority. 'In authentic contextualization the cultural story and its lived expression must be evaluated from the standpoint of Scripture, not the other way around' (Goheen 2014:290). Missional exegesis takes as its point of departure the unnegotiable truth of the grand narrative, the biblical story, and recognises that the Gospel is never a disembodied message, but 'is always incarnated and expressed, in word or life, in some cultural idiom' (Goheen 2014:288) in the context of a missionary encounter with culture. ${ }^{13}$

The article has demonstrated that a missional exegesis is a prerequisite for the biblical text to be able to effectively and biblically address the specific contextual needs of the ethne in the context of missions, but also for the church in the western context of plural and multicultural societies. Missional exegesis heeds the call of Goheen (2014:409) that 'a fresh approach to missions today must begin with a return to Scripture'.

\section{Conclusion}

Missional exegesis draws the reader into a fruitful dialogue with the text from his unique contextual vantage point to participate in God's mission, the missio Dei. It is textual and contextual, that is, it arises from a specific cultural context and it addresses that cultural context through the exegesis of Scripture. It is an exegesis which gives equal consideration to 13.It has to be distinguished from a missional church encounter with the culture. 
both text and context and is able to provide missional applications and implications which are both practical, relevant and biblical. The starting point for such an exegesis can be from either the text or the context, from text to context or from context to text, as equal attention and priority is given to both. It provides a fruitful reflection on a specific missional context through the lens of the biblical text.

\section{Acknowledgements Competing interests}

The authors declare that they have no financial or personal relationships which may have inappropriately influenced them in writing this article.

\section{Authors' contributions}

L.L-M. contributed towards this article in terms of the perspective on ethnohermenuetics. The contribution of L.L-M. is made as a reflection on the Consultation of Anthropologists and Theologians, Biola University, 14-15 April 1986. The concept of the need for a missional exegesis is the result of reflection of L.L-M. and T.A.v.A. as part of lecturing the M.A program at International Leadership University (ILU), Burundi. T.A.v.A. worked on a missional exegetical approach to the letter of Ephesians, from 'text to context'. A model was suggested by L.L-M. in which the movement from 'context to text' be considered of equal importance to the movement from 'text to context'. L.L-M. contributed the missiological reflections and implication and the figures 1 and 2 .

\section{References}

Barram, M.D., 2007, 'The Bible, mission and social location: Toward a missional hermeneutic', Interpretation 61(1), 42-58. https://doi.org/10.1177/00209643000 6100106

Bekele, G., 2011, 'The biblical narrative of the missio Dei: Analysis of the interpretive framework of David Bosch's missional hermeneutic', International Bulletin of Missionary Research 35(3), 153-158. https://doi.org/10.1177/2396939311 03500309

Bevans, S.B., 2002, Models of contextual theology, 2nd edn., Orbis Books, New York. (Faith \& culture series)

Bosch, D., 1980, Theology of mission and science of religion MSR 201 study guide, University of South Africa, Pretoria. https://doi.org/10.1163/157338386X00312

Bosch, D., 1986. 'Towards a hermeneutic for biblical studies and mission', Mission Studies 3(2), 65-79.

Bosch, D., 1991. Transforming mission: Paradigm shifts in theology of missions, Orbis Books' New York.

Caldwell, L.W., 1986, 'Third horizon ethnohermeneutics: Re-evaluating New Testament hermeneutical models for intercultural Bible interpreters today', Paper presented to Consultation of Anthropologists and Theologians, Biola University, 14-15 April 1986.

Caldwell, L.W., 2005, 'Towards an ethnohermenutical model for a lowland Filipino context,. Journal of Asian Mission 7(2), 169-193.
Caldwell, L.W., 2013, Interpreting the Bible with the poor, Asbury Theological Seminary, Association of Professors, Mission APM Conference 2013, First Fruits Press, Association

Clark, D., 2003, To know and love God: Method for theology, Crossway, Wheaton.

Counted, V., 2016, 'Missionising youth identity crisis: Towards a missional hermeneutic of coping in youth ministry practice', Missionalia 44(1), 85-102. https://doi. org/10.7832/44-1-141

Dryness, W.A., 1991, Learning about theology from the Third World, Zondervan, Grand Rapids.

Du Plessis, J.G., 1990 'For reasons of the heart: A critical appraisal of David J. Bosch's use of Scripture in the foundation of Christian mission', Missionalia 18(1), 75-85.

Fanning, B.M., 2006, 'Theological analysis: Building biblical theology', in D.L. Bock \& B.M. Fanning (eds.), Interpreting the New Testament text: Introduction to the art and science of exegesis, pp. 277-293, Good News Publishers, Wheaton. (Crossway Books).

Fee, G.D. \& Stuart, D., 2002, How to read the Bible book by book, Zondervan, Grand Rapids.

Gadamer, H.G., 2002, Truth and method, 2nd rev. edn., trans. J. Weinsheimer \& D.G. Marshall, Continuum, New York.

Grenz, S.J., Guretzki, D. \& Nordling, C.F., 1999., Pocket dictionary of theological terms, InterVarsity, Grand Rapids.

Goheen, M.W., 2014, Introducing Christian mission today: Scripture, history and ideas, InterVarsity Academic, Downers Grove.

Gorman, M.J., 2009. Elements of biblical exegesis: A basic guide for students and ministers, Hendrickson, Peabody.

Hayes, J.H. \& Holladay, C.R., 2007, Biblical exegesis: A beginner's handbook, John Know Press, Westminster.

Hesselgrave, D.J., 2006, 'Syncretism: Mission and missionary induced?', in G. van Rheenen (ed.), Contextualization and syncretism: Navigating cultural differences, pp. 71-98, William Carrey Library, Pasadena. (EMS Series, no. 13).

Hesselgrave, D.J. \& Rommen, E., 1989, Contextualization: Meanings, methods, and models, Baker Book House: Grand Rapids.

Hoehner, H.W., 2002, Ephesians: An exegetical commentary, Baker Academic, Grand Rapids.

Hunsberger, G.R., 2011, 'Proposals for a missional hermeneutic: Mapping a conversation', Missiology: An International Review 39(3), 309-321. https://doi. org/10.1177/009182961103900302

Kaizer, W.C., 1981, Toward an exegetical theology: Biblical exegesis for preaching and teaching, Baker Book House: Grand Rapids.

McDonald, J.I.H., 1990, 'Hermeneutical circle', in R.J. Coggins \& J.L. Houlden (eds.), A dictionary of biblical interpretation, pp. 281-282, Trinity Press International, Philadelphia.

McGrath, A.E., 2010., Mere apologetics: How to help seekers \& sceptics find faith, Baker Books: Grand Rapids.

Míguez, N.O., 2000, 'Hermeneutical circle', in V. Fabella \& R.S. Sugirtharajah (eds.) A dictionary of Third World theologies, p. 97, Orbis, New York.

Mills, M.F., 2007, Alterity, pain, and suffering in Isaiah, Jeremiah and Ezekiel, Clark International, New York.

O'Brien, P., 1999, The letter to the Ephesians, Eerdmans, Grand Rapids.

O'Brien, P., 2004, 'The summing up of all things', in P.J Williams, A.D Clarke, P.M. Head \& D. Instone-Brewer (eds.), The New Testament in its first century setting, pp. 165-177, Eerdmans, Grand Rapids.

Ott, C., Strauss, J.C. \& Tennent, T.C., 2010, Encountering theology of mission: Biblical foundations, historical developments, and contemporary issues, Baker Academic, Grand Rapids.

Turabian, K., 2007, A manual for writers of term papers, thesis, and dissertations, 7th edn., University of Chicago Press, Chicago.

Vanhoozer, K.J., 2005, 'Discourse on matter: Hermeneutics and the miracle of understanding', International Journal of Systematic Theology 7(1), 5-37. https:// doi.org/10.1111/j.1468-2400.2005.00149.x

Van Aarde, T.A., 2016.' 'The use of oikovouía for missions in Ephesians', Verbum et Ecclesia 37(1), a149, http://dx.doi.ord/10.4102/ve.v37il.1489

Vanhoozer, K.J., 2006, 'One rule to rule them all?: Theological method in an era of world Christianity', in C. Ott \& H.A. Wetland (eds.), Globalizing theology: Belief and practice in an era of world Christianity, pp. 85-126, Baker Academic, Grand Rapids.

Wright, C.J.H., 2006, The mission of God: Unlocking the Bible's grand narrative, InterVarsity, Nottingham. 